DOI: $10.22630 / E I O G Z .2014 .105 .4$

Zeszyty Naukowe Szkoły Głównej Gospodarstwa Wiejskiego

Ekonomika i Organizacja Gospodarki Żywnościowej nr 105, 2014: 45-56

Elżbieta Jadwiga Szymańska, Magdalena Stefaniak

Wydział Nauk Ekonomicznych

Szkoła Główna Gospodarstwa Wiejskiego w Warszawie

\title{
Znaczenie ruchu przygranicznego w rozwoju społeczno-gospodarczym gmin wschodniej Polski
}

\section{Wstęp}

Przystąpienie Polski do Unii Europejskiej spowodowało, że wschodnia granica kraju (poza niewielkim odcinkiem graniczącym z Litwą) stała się jednocześnie zewnętrzną granicą Wspólnoty. W ten sposób pojawiła się konieczność nowego jakościowo podejścia do skutków istnienia tej granicy dla położonych wzdłuż niej polskich województw, podobnie jak sąsiadujących z nią regionów Rosji, Białorusi i Ukrainy. Kolejnym krokiem w ramach integracji europejskiej było wejście Polski do strefy Schengen. Z jednej strony polscy obywatele uzyskali możliwość w pełni swobodnego podróżowania po obszarze Schengen, a z drugiej, zobligowało to Polskę do uszczelnienia wschodniej granicy.

Położenie przygraniczne wschodniej Polski stanowi dla tego regionu jednocześnie szansę i zagrożenie. Mało stabilna sytuacja w krajach sąsiednich skłania do prowadzenia zbalansowanej polityki regionalnej (tzn. polityki identyfikującej i wspierającej różne endogeniczne czynniki rozwoju) [Komornicki, Miszczuk 2012]. Jednym z nich jest ruch graniczny, który stanowi przejaw aktywności społecznej i gospodarczej. Wzdłuż szlaków, którymi przebiega, wokół przejść granicznych tworzą się naturalne mniejsze i większe centra aktywności gospodarczej i centra wzrostu. Różnice w poziomie cen towarów i wysokości dochodów mieszkańców miejscowości przygranicznych wpływają na rozwój handlu [Powęska 2011]. Dlatego dla regionów przygranicznych ruch na granicy państwa jest istotnym elementem życia gospodarczego i powinien być uwzględniany jako ważny czynnik potencjalnego rozwoju regionalnego 
i lokalnego we wszystkich dokumentach o charakterze programowym. Wiele analiz dotyczących regionów wschodniej Polski wskazuje bowiem na to, że dla tych obszarów głównymi czynnikami rozwojowymi będzie wzrost transgranicznej wymiany gospodarczej, wykorzystanie funduszy strukturalnych oraz wsparcie ze strony przygotowanych przez UE programów.

Wobec gwałtownych i niejednokrotnie skokowych zmian na obszarach przygranicznych wschodniej Polski położenie gmin przy przejściu granicznym może stać się szansą na przyspieszenie rozwoju. Pojawia się zatem pytanie, czy działalność pozarolnicza w gminach Piszczac i Terespol jest właściwą strategią rozwoju tych gmin? Jakie zajęcia okołorolnicze i inne możliwości mogą zmienić strukturę funkcjonowania tych gmin, zwłaszcza że zmiana funkcji wsi jest bardzo skomplikowana. Modernizacja, zmiany mentalności społeczności wiejskiej, dywersyfikacja funkcji to proces złożony i długotrwały, zależny od przemian zewnętrznych i wewnętrznych.

Regiony przygraniczne ze względu na swoje peryferyjne położenie są zagrożone marginalizacją. W ich rozwoju należy wykorzystać obiektywne uwarunkowania wewnętrzne i zewnętrzne, w tym również specyficzność wynikającą z przygranicznego położenia [Ślusarz 2008].

\section{Cel i metodyka badań}

Przedmiotem analiz w opracowaniu jest problem obszaru pogranicza, jako miejsca kształtowania się zjawisk społeczno-kulturowych i gospodarczych. Celem badań było rozpoznanie znaczenia ruchu przygranicznego dla rozwoju gmin położonych przy wschodniej granicy. W opracowaniu sformułowano hipotezę, że położenie przygraniczne ma pozytywny wpływ na rozwój gmin.

Badaniami objęto dwie gminy: Terespol i Piszczac. Ich wybór wynikał z przygranicznego położenia i rolniczego charakteru. W analizach wykorzystano studia literatury przedmiotu oraz dane statystyczne GUS i Urzędu Statystycznego w Lublinie dotyczące poziomu bezrobocia, przedsiębiorczości, produktu krajowego brutto (PKB) oraz wielkości migracji. Ponadto przygotowano kwestionariusz wywiadu kierowanego, na podstawie którego w 2010 roku przeprowadzono badania wśród 140 mieszkańców tych gmin. W badaniach wzięło udział 70 osób w gminie Terespol i 70 w gminie Piszczac. Były to osoby w wieku od 20 do 65 lat, o różnym poziomie wykształcenia i osiąganych dochodach. Dobrano je w sposób celowy, aby uwzględnić poglądy różnych grup społecznych i zawodowych na temat barier i możliwości rozwoju przygranicznych gmin. Badaniami objęto osoby zatrudnione w sektorze publicznym i prywatnym, emerytów i rencistów, uczniów i studentów, rolników oraz bezrobotnych. Decydującym 
kryterium doboru respondentów była ich zgoda na wypełnienie ankiety. Na podstawie zebranych opinii określono pozytywne i negatywne aspekty rozwoju ruchu przygranicznego. Wyniki badań przedstawiono w formie opisowej, na wykresach i w tabelach.

\section{Charakterystyka terenu badań}

Gminy Terespol i Piszczac należą do powiatu bialskiego. Mimo położenia przygranicznego cechuje je niski rozwój lokalnej przedsiębiorczości. Wynika to z monofunkcyjności rolniczej oraz niedorozwoju infrastruktury. Brak miejsc pracy wpływa na wzrost migracji i zwiększa liczbę bezrobotnych. W październiku 2012 roku w powiecie bialskim przeciętna stopa bezrobocia wynosiła 14,9\%. W 2010 roku granicę Polski z Białorusią na poziomie województwa lubelskiego przekroczyło 3416,7 tys. osób, w tym 2615,1 przejściem drogowym i kolejowym przez Terespol [Ruch... 2011].

Gmina Terespol położona jest wzdłuż rzeki Bug, w granicach Nadbużańskiego Obszaru Chronionego Krajobrazu. Obfituje ona w cenne przyrodniczo i krajobrazowo tereny: Parku Krajobrazowego „Podlaski Przełom Bugu” oraz rezerwaty przyrody „Czapli Stóg” i „Szwajcaria Nepelska”. Gmina leży na historycznym szlaku łączącym wschód i zachód Europy. Specjalnym atutem gminy są przecinające się szlaki komunikacyjne: droga E-30 łącząca Lizbonę i Londyn z Moskwą przez Paryż - Berlin - Warszawę - Mińsk oraz linia kolejowa E-20 z Paryża do Moskwy, tworzące europejski korytarz transportowy nr 2. Ruch graniczny odbywa się przez trzy przejścia graniczne zlokalizowane na terenie gminy:

- w Kukurykach dla TIR-ów,

- „Warszawski Most” (Terespol) dla samochodów osobowych i autobusów,

- przejście kolejowe.

W 2010 roku średni wskaźnik nasycenia przedsiębiorczością w gminie Terespol był wyjątkowo niski i wynosił 40,3 przedsiębiorstw na 1000 mieszkańców [Statystyczne... 2012]. Prawie 79,4\% stanowiły przedsiębiorstwa usługowe, 8,3\% budowlane, a pozostałe prowadziły działalność przemysłową.

Gmina Piszczac położona jest na terenie Polesia Zachodniego. Przez terytorium gminy przepływają niewielkie rzeczki i dominuje tu typowo podlaski krajobraz: rozległe równiny z często występującymi kompleksami leśnymi, poprzecinane gdzieniegdzie krętymi rzeczkami i bagnami. Atrakcją turystyczną gminy są zabytki podlaskiej architektury sakralnej, zwłaszcza cerkiewki unickie. Gmina posiada rolniczy charakter. Ponad 65\% jej obszaru stanowią UR, ale tylko $1 / 4$ gospodarstw domowych utrzymuje się z pracy w rolnictwie. Przeważają tam 
gospodarstwa indywidualne o małej powierzchni i słabej jakości gleb. Średni wskaźnik nasycenia przedsiębiorczością w gminie Piszczac w 2010 roku był niski i wynosił 44,5 przedsiębiorstw na 1000 mieszkańców [Statystyczne... 2012]. Główną grupę stanowią osoby fizyczne prowadzące działalność gospodarczą (75,4\% ogółu). Podobnie rozkłada się podział przedsiębiorstw ze względu na podstawowe typy działalności. Ponad 71,8\% podmiotów gospodarczych prowadziło działalność usługowa, 12,3\% działało w branży budowlanej, a pozostałe 6,9\% to jednostki przemysłowe.

Przygraniczne położenie gmin wiąże się z możliwością kontaktów handlowych i kooperacyjnych ze wschodnimi sąsiadami. W 2010 roku wschodnią granicę UE przekroczyło 16068 tys. cudzoziemców i 5644 tys. Polaków [Ruch... 2011]. Współpraca transgraniczna realizowana jest na różnych szczeblach i w rozmaitych formach, lecz najczęściej na podstawie lokalnych i regionalnych zasobów naturalnych i potencjałów intelektualnych.

\section{Znaczenie granicy wschodniej}

Wschodnia granica Polski ma kluczowe znaczenie dla Unii Europejskiej ze względów: bezpieczeństwa, ekonomicznych oraz społecznych. Jednocześnie stawia wiele wyzwań. Najważniejsze z nich dotyczą problemu tzw. „miękkiego bezpieczeństwa” (związanego z przemytem, nielegalną migracją przestępczością zorganizowaną itp.). Ponadto, przez granicę tę przebiegają prawie wszystkie najważniejsze korytarze transportowe, szlaki komunikacyjno-handlowe łączące Europę z obszarem Eurazji. Granica ta dzieli obszary zamieszkiwane przez ludność bliską sobie kulturowo i historycznie, którą łączą związki społeczne, a także etniczne.

Cechą charakterystyczną obszarów po obu stronach nowej granicy wschodniej UE jest ich peryferyjność. W zdecydowanej większości są to obszary rolnicze, o znacznie gorszych wskaźnikach ekonomicznych niż reszta kraju. W podobnym stopniu dotyczy to regionów po obu stronach granicy. Są to też regiony niedoinwestowane, o znacznie wyższym od średnich krajowych poziomie bezrobocia, bez dużych ośrodków przemysłowych (poza miastami Kaliningrad, Grodno, Brześć, Olsztyn, Białystok, Lublin, Łuck i Lwów).

Według danych z 2010 roku, poziom PKB na 1 mieszkańca w województwach położonych przy wschodniej granicy (warmińsko-mazurskim, podlaskim, lubelskim i podkarpackim) był najniższy w skali całego kraju. Województwa te zajmowały pod względem tego wskaźnika cztery ostatnie miejsca, przy czym w żadnych z nich poziom PKB na mieszkańca nie osiagnął 80\% średniej krajowej (wynoszącej wówczas 29,7 tys. zł), a w województwie najsłabszym (podkarpackim) wynosił zaledwie 67,3\% tej średniej [Rocznik... 2012]. 
W regionach wschodnich występuje także wysoka stopa bezrobocia. W październiku 2012 roku była ona wyższa od średniej krajowej, która wynosiła 12,5\%. W województwie warmińsko-mazurskim wskaźnik ten był najwyższy i wynosił aż 19,8\% [Monitoring... 2012]. Stosunkowo umiarkowany (statystyczny) poziom bezrobocia jest jedynie efektem znacznego udziału rolnictwa w strukturze bazy ekonomicznej województw wschodnich opartego na tradycyjnych gospodarstwach rodzinnych. Gospodarstwa te dają zatrudnienie istniejącym faktycznie nadwyżkom siły roboczej. W tej sytuacji niezbędny jest rozwój przedsiębiorczości na tych terenach. Nowe miejsca pracy stanowią szansę na ograniczenie bezrobocia, w tym zmniejszenie nadmiaru osób pracujących w rolnictwie.

Dowodem na niską atrakcyjność osiedleńczą obszarów położonych przy wschodniej granicy, jest postępująca ucieczka ludności z tych terenów. Proces ten ma niewątpliwie podłoże ekonomiczne i wiąże się z poszukiwaniem lepszych szans życiowych. W 2009 roku wszystkie województwa przy granicy wschodniej dotknięte były ujemnym saldem migracji. W województwach lubelskim i warmińsko-mazurskim skala ubytku migracyjnego w ciagu roku przekroczyła $1,9 \%$.

Głównymi kierunkami odpływu ludności z tego obszaru są przede wszystkim najszybciej rozwijające się aglomeracje miejskie w Polsce oraz ośrodki zagraniczne. Sytuację tę należy ocenić jako bardzo niekorzystną, tym bardziej, iż wiadomo jest, że rzeczywista skala emigracji zagranicznej jest znacznie większa. Co więcej - straty demograficzne regionów przygranicznych nie mają jednak wyłącznie charakteru ilościowego. Odpływ osób młodych, przedsiębiorczych, odważnych w podejmowaniu decyzji, odbija się niekorzystnie na poziomie aktywności ekonomicznej i społecznej ludzi, którzy tutaj pozostają. W szczególności bierność mieszkańców zauważalna jest na obszarze województwa warmińsko-mazurskiego, gdzie skutki emigracji osób najaktywniejszych nakładają się na utrwaloną od dziesięcioleci bierność znacznej części mieszkańców wsi „popegeerowskich" [Kawałko 2010].

Z drugiej jednak strony peryferyjność w dużym stopniu sprzyja rozwijaniu kontaktów transgranicznych, wzajemnemu budowaniu nowego typu potencjałów gospodarczych oraz relacji w zakresie:

- rozwoju gospodarczego i wspierania kontaktów przygranicznych,

- związków kulturowo-społecznych,

- transferu know-how,

- wymiany kulturalnej,

- wymiany doświadczeń między samorządami.

Ze względu na bezpośrednie sąsiedztwo UE z trzema państwami wschodniej Europy, o bardzo dużym potencjale ekonomiczno-społecznym oraz kluczowo 
położonych geopolitycznie, istnieje konieczność wzmocnienia i budowania programów wspierających współpracę międzyregionalną i transgraniczną. Istotnym czynnikiem rozwoju jest także właściwa promocja gmin [Kłodziński 2000].

\section{Rozwój przedsiębiorczości w gminach wschodnich}

Analizowane gminy mają wiele atutów, które można wykorzystać w rozwoju przedsiębiorczości na tych terenach. Ich walorami są przede wszystkim bezcenne obszary niezdegradowanych ekosystemów nadbużańskiej przyrody, naturalny krajobraz, różnorodność zabytków i tradycje kulturowe [Strategia... 2008]. Specyficznym miejscem jest dolina Bugu, która ze względu na brak regulacji zachowała swój dziki charakter, czyli kręty bieg z licznymi zakolami, starorzeczami i naturalną, bogatą roślinnością. Uroku okolicy dodają wioski nadbużańskie, gdzie można spotkać tradycyjną, drewnianą zabudowę. Występowanie obszarów o cennych walorach przyrodniczych i kulturowych, wolne tereny do zagospodarowania i brak uciążliwego przemysłu mogą przyczynić się do rozwoju turystyki w tym regionie.

Gminy Piszczac i Terespol należą do typowo rolniczych. Dominują tam gospodarstwa indywidualne o małej powierzchni, poniżej 10 ha, o tradycyjnych metodach produkcji. Czyste środowisko i rolniczy charakter gmin stwarzają możliwości do produkcji zdrowej i ekologicznej żywności.

Do barier rozwoju przedsiębiorczości na terenach gminy Terespol i Piszczac można zaliczyć: strukturę gospodarki, charakter rolnictwa oraz brak działań lokalnych i regionalnych instytucji na rzecz rozwoju gmin. Duży problem stanowi rozdrobnienie gospodarstw rolnych i ich wielokierunkowość. Większość rolników produkuje wyłącznie dla siebie oraz na lokalny rynek, osiągając niskie dochody. Słabą stroną badanych gmin jest także brak zakładów przetwórstwa rolnego i niedostateczna infrastruktura. Ponadto, z funkcjonowaniem gospodarstw rolniczych związane jest zjawisko ukrytego bezrobocia. W tym zakresie dynamika zmian nie jest zadowalająca. Przedsiębiorczość wiejska napotyka na bariery rozwoju, które obejmują ograniczony popyt lokalny, wysokie koszty zaopatrzenia i reklamy.

Bliskość granicy stanowi jednak szansę rozwoju nowych miejsc pracy. Lokalne przedsiębiorstwa nastawione na klienta zagranicznego prowadzą przede wszystkim działalność handlową. Ich obecna sytuacja rodzi jednak pewne wątpliwości, co do dalszego funkcjonowania. Problem stanowi bowiem bierna polityka państwa wobec wschodnich klientów, brak luksusowych towarów w ofercie oraz ograniczona reklama. Głównymi klientami przedsiębiorstw handlowych są osoby przyjeżdżające zza wschodniej granicy, które za zakupiony towar płacą 
gotówką. Przy zamówieniach specjalnych stosowana jest zasada ograniczonego zaufania, które polega na tym, że zlecenie wykonywane jest tylko w wypadku dużej przedpłaty bądź realizacji całej płatności.

Uszczelnienie granicy oraz kryzys gospodarczy przyczyniły się do zmniejszenia liczby przedsiębiorstw handlujących z krajami zza wschodniej granicy. Dotyczyło to przede wszystkim podmiotów nastawionych na produkcję wyrobów niskiej jakości, niemających zbytu na krajowym rynku.

Głównym zagrożeniem dla przedsiębiorstw funkcjonujących w gminach przy wschodniej granicy jest słabo rozwinięta infrastruktura techniczna oraz brak kapitału na nowe inwestycje. Niebezpieczny jest także postępujący proces starzenia się ludności i ujemny przyrost naturalny. Czynniki te w połączeniu z migracją młodych ludzi mogą doprowadzić w przyszłości do wyludnienia tych terenów. Inne zagrożenia w funkcjonowaniu gmin dotyczą spadku dochodów gmin, nadprodukcji w rolnictwie oraz niechęci mieszkańców do zmiany swojej sytuacji życiowej. Część z zagrożeń wynika z przystapienia Polski do Unii Europejskiej i konieczności znacznego uszczelnienia wschodniej granicy (wizy, zaostrzona kontrola celna).

\section{Skutki rozwoju ruchu przygranicznego dla gmin wschodnich}

Grupa respondentów, która wzięła udział w badaniach, była zróżnicowana pod względem poziomu wykształcenia i miejsca zatrudnienia. W gminie Piszczac dominowały osoby ze średnim wykształceniem, a w gminie Terespol z wyższym (rys. 1).

W analizowanej grupie ponad 60\% pracowników było zatrudnionych w przedsiębiorstwach państwowych (rys. 2). W gminie Piszczac znaczny odsetek stanowili emeryci i renciści (15\%), a w gminie Terespol bezrobotni (20\%). Ponadto, w pierwszej z tych gmin udział w badaniach wzięli także rolnicy, którzy stanowili $10 \%$ próby. Z kolei udział osób pracujących w przedsiębiorstwach prywatnych wynosił jedynie $5 \% \mathrm{w}$ obu gminach.

Pytania zawarte w kwestionariuszu dotyczyły znaczenia ruchu granicznego dla rozwoju gmin, który jest istotnym elementem życia gospodarczego, zwłaszcza dla mieszkańców przygranicznych gmin. Z badań GUS wynika, że w II kwartale 2010 roku przekraczający zewnętrzną granicę Unii Europejskiej cudzoziemcy, podobnie jak i Polacy, byli najczęściej mieszkańcami miejscowości zlokalizowanych w odległości do $50 \mathrm{~km}$ od granicy [Badanie... 2010]. W tym samym pasie cudzoziemcy ponieśli 67,8\% wydatków w Polsce, a Polacy zrealizowali 91,5\% wydatków za granicą. 
52

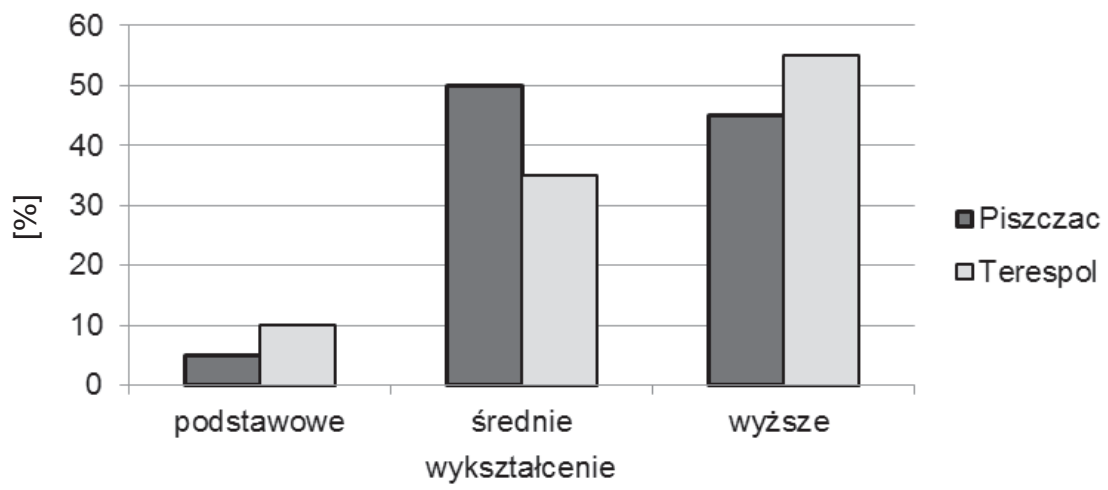

Rysunek 1

Zróżnicowanie poziomu wykształcenia wśród respondentów

Źródło: Badania własne.

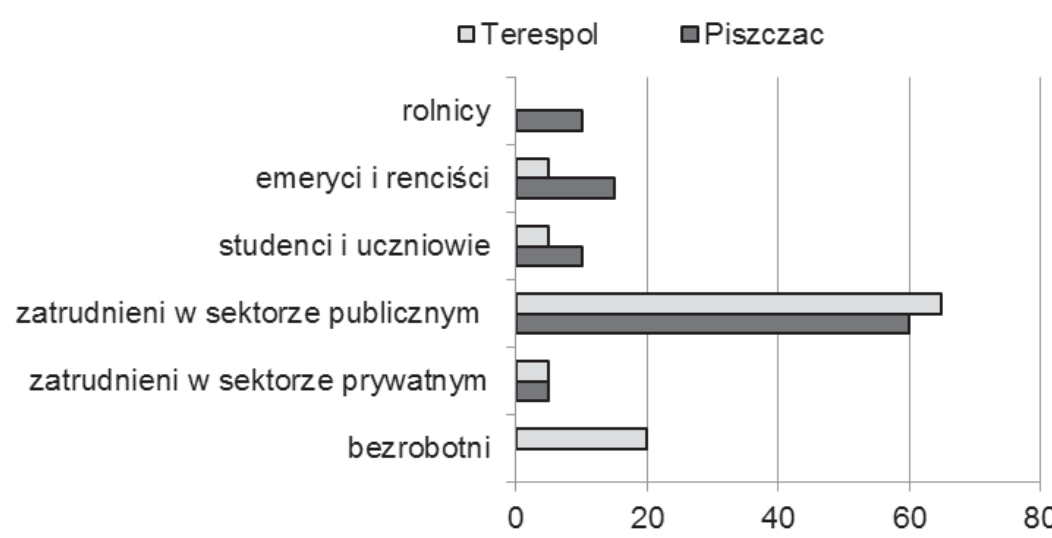

Rysunek 2

[\%]

Zróżnicowanie miejsc zatrudnienia i źródeł dochodów respondentów

Źródło: Badania własne.

Na pytanie, czy na rozwój gminy wpływa ruch graniczny 92,5\% ankietowanych mieszkańców gmin odpowiedziało twierdząco (rys. 3). Wśród pozytywnych elementów respondenci najczęściej wymieniali rozwój handlu (50\%) oraz wzrost gospodarczy (33\%).

Zdaniem ankietowanych, ruch przygraniczny ma mniejsze znaczenie w rozwoju turystyki i tworzeniu nowych miejsc pracy. W niewielkim zakresie przyczynia się do współpracy między przedsiębiorstwami z sąsiednich krajów. Jeszcze mniejszy wpływ ma na zawieranie nowych znajomości oraz poznawanie odmiennej kultury. 


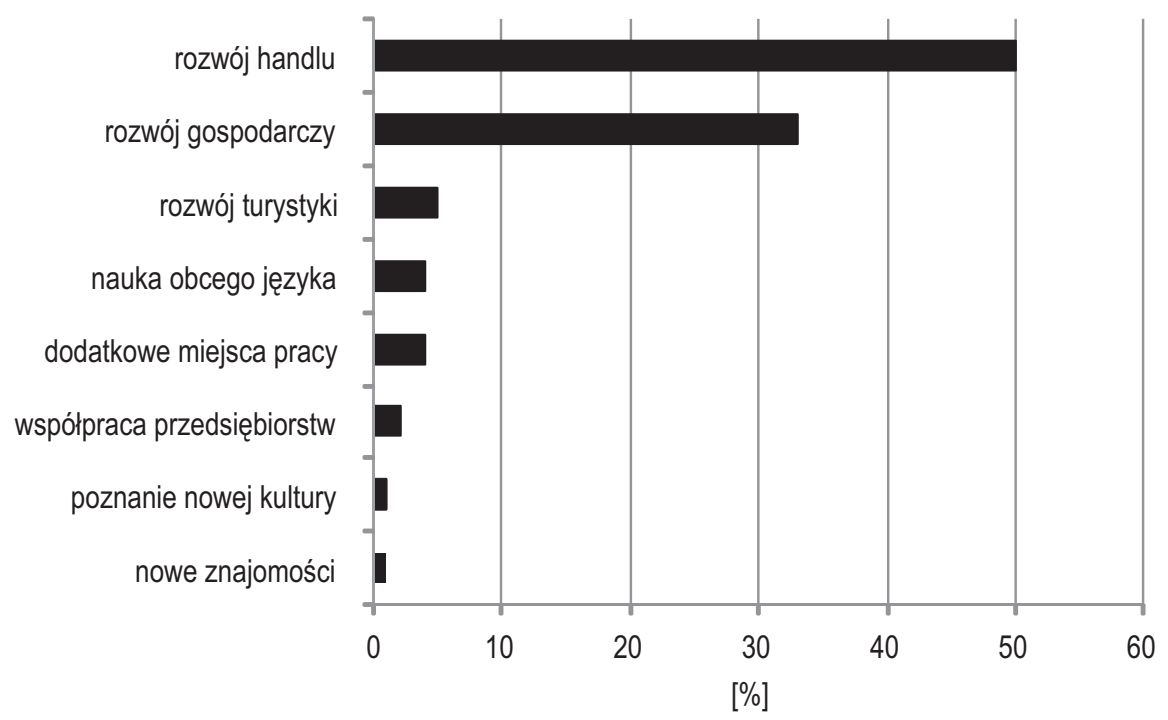

\section{Rysunek 3}

Pozytywne skutki rozwoju ruchu przygranicznego

Źródło: Badania własne.

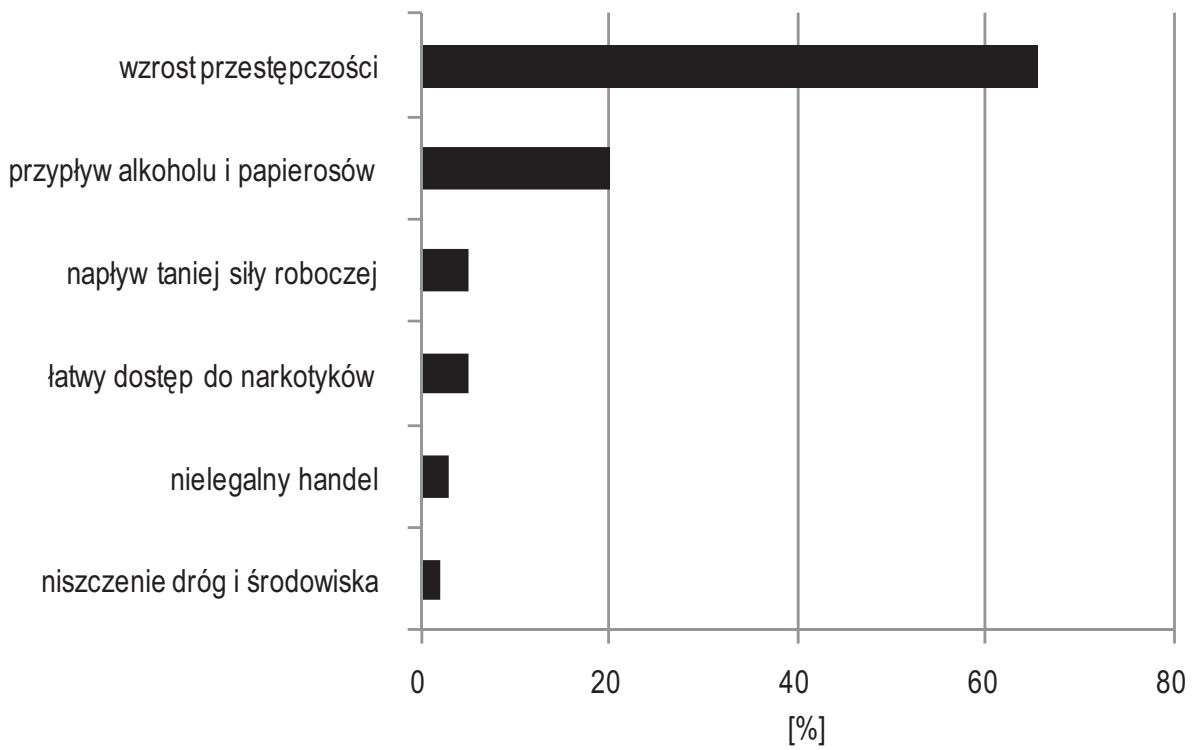

Rysunek 4

Negatywne skutki rozwoju ruchu przygranicznego

Źródło: Badania własne. 
Wśród negatywnych aspektów ruchu przygranicznego respondenci najczęściej wymieniali wzrost przestępczości oraz nielegalny przepływ alkoholu i papierosów (rys. 4). Na pierwszy z tych elementów wskazało 65\% ankietowanych, a na drugi $20 \%$. Zaledwie $2 \%$ badanych osób stwierdziło, że ruch przygraniczny wpływa na niszczenie środowiska i dróg. Podobny odsetek wskazał na rozwój nielegalnego handlu.

Zdaniem ankietowanych, ruch przygraniczny zwiększa napływ taniej siły roboczej zza wschodniej granicy oraz stwarza łatwiejszy dostęp do narkotyków. Przyczynia się do mieszania kultur sąsiednich państw (45\%), różnych tradycji religijnych (35\%) oraz przemieszczania się ludności i tworzenia nowych wspólnot (20\%). W zakresie tych, trzech aspektów respondenci wskazywali na ich pozytywne i negatywne oddziaływanie.

W zakresie elementów, które można poprawić w gminach, mieszkańcy najczęściej wskazywali konieczność budowy nowych i modernizacji starych dróg. Ich zdaniem należy zmienić estetykę otoczenia, ponieważ od niej zależy wizerunek gminy. Działania w tym zakresie wymagają jednak pozyskania środków finansowych oraz właściwego ich rozdysponowania. Ważnym zagadnieniem jest także zmniejszenie bezrobocia, poprawa dostępu do służby zdrowia oraz promocja regionu.

\section{Wnioski}

Przedmiotem dociekań w opracowaniu było kształtowanie się zjawisk kulturowych, społecznych i gospodarczych na obszarze przygranicznym wobec gwałtownych i niejednokrotnie skokowych zmian na wschodniej granicy. Postawiona hipoteza, według której położenie przygraniczne ma pozytywny wpływ na rozwój gmin, nie została udowodniona. Zdaniem przedstawicieli mieszkańców badanych gmin, ruch przygraniczny przyczynia się do rozwoju handlu i gospodarki, ale jednocześnie wpływa na wzrost przestępczości i niekontrolowany przepływ alkoholu i papierosów.

1. Słabość przygranicznych gmin wynika zarówno z ich oddalenia od większych miast, mogących wpłynąc stymulująco, dominującej struktury gospodarczej (nieefektywne małe gospodarstwa rolnicze), jak i niskiej społecznej mobilizacji, przy braku zewnętrznych impulsów rozwoju. W perspektywie najbliższych lat te trudności nie zostaną zniwelowane, a rozwój tych obszarów będzie uzależniony od bliskości subregionalnych ośrodków wzrostu.

2. Z badań wynika, że w gminie Piszczac i Terespol występuje niski stopień nasycenia przedsiębiorczością. Dominują tam przedsiębiorstwa osób 
fizycznych, które prowadzą działalność usługową. Gminy mają charakter rolniczy, ale większość użytkowników gospodarstw rolnych produkuje wyłącznie na swoje potrzeby i osiaga niskie dochody. Do poprawy tej sytuacji niezbędna jest zmiana postaw i większa przedsiębiorczość rolników oraz zakrojona na szeroką skalę modernizacja gospodarstw.

3. Mała liczba przedsiębiorstw i brak nowych inwestycji ograniczają zatrudnienie w gminach wschodniej Polski. Duża liczba osób w wieku produkcyjnym nie ma możliwości rozwoju zawodowego i migruje do dużych ośrodków miejskich albo poza granice kraju. Część z tych osób pozostaje jednak w gospodarstwach rolnych, przez co pogłębia się poziom ukrytego bezrobocia. W tej sytuacji niezbędny jest rozwój przedsiębiorczości oraz budowa nowej i modernizacja istniejącej infrastruktury. Stanowi to szansę na ograniczenie bezrobocia i zmniejszenie nadmiaru osób pracujących w rolnictwie.

4. W związku z małych popytem wewnętrznym miejscowe przedsiębiorstwa uzależnione są od kontaktów handlowych z Rosją i Białorusią. Producenci i handlowcy stosują jednak wobec klientów zza wschodniej granicy bierną politykę handlową. Oznacza ona brak stałych kontraktów oraz załatwianie transakcji tylko za gotówkę. Przy dużych zamówieniach istnieje ograniczone zaufanie i nie stosuje się żadnych form kredytowania. Taka polityka rodzi obawy odnośnie dalszej współpracy.

5. Rozwój społeczno-gospodarczy w gminach jest niemożliwy bez wsparcia instytucjonalnego małych firm oraz podnoszenia kwalifikacji ludności bezrobotnej. Priorytetem działań samorządów powinno być pozyskiwanie nowych środków finansowych na inwestycje gospodarcze i szkolenia. Istotne jest także wykorzystanie walorów przyrodniczych gmin dla potrzeb rozwoju turystyki i rekreacji oraz zwiększenie obrotów handlu i współpracy z podmiotami gospodarczymi zza wschodniej granicy.

\section{Literatura}

Badanie obrotu towarów i usług w ruchu granicznym na granicy zewnętrznej Unii Europejskiej na terenie Polski w II kwartale 2010 roku. Urząd Statystyczny w Rzeszowie, 2010.

KAWAŁKO B., Granica wschodnia jako czynnik ożywienia i rozwoju społeczno-ekonomicznego regionów przygranicznych, http://www.mrr.gov.pl/rozwoj_regionalny/poziom_regionalny/strategia_rozwoju_polski_wschodniej_do_2020/dokumenty/Documents/b3fd8a3c919b4f59a5d7b1be771706a7Kawako.pdf (dostęp: 14.08.2013).

KŁODZIŃSKI M., 2000: Przedsiębiorczość na obszarach wiejskich, [w:] Rozwój przedsiębiorczości na terenach wiejskich wschodniego i zachodniego pogranicza, Kłodziński M. (red.), PAN, IRWiR, Warszawa. 
KOMORNICKI T., MISZCZUK A., 2012: Transgraniczne powiązania województw Polski wschodniej. Ekspertyza wykonana na zlecenie Ministerstwa Rozwoju Regionalnego na potrzeby aktualizacji Strategii rozwoju społeczno-gospodarczego Polski Wschodniej do roku 2020.

Monitoring Rynku Pracy. Miesięczna informacja o bezrobociu rejestrowanym w Polsce w październiku 2012 roku. GUS, Warszawa 2012.

POWE SKA H., 2011: Functions of retail trade in the borderlands of Poland - a theoretical perspective. Acta Scientiarum Polonorum Oeconomia 10 (2), 65-74.

Rocznik Statystyczny Województw, GUS, Warszawa 2012.

Ruch graniczny oraz przepływ towarów i usług na zewnętrznej granicy Unii Europejskiej na terenie Polski w 2010 roku, GUS, Urząd Statystyczny w Rzeszowie, Warszawa-Rzeszów 2011, http://www.stat.gov.pl/cps/rde/xbcr/rzesz/ASSETS_ruch_na_zewn_gran. pdf (dostęp: 10.02.2014).

Statystyczne Vademecum Samorządowca. Urząd Statystyczny w Lublinie, 2012.

Strategia rozwoju gminy Piszczac na lata 2008-2015, http://www.powiatbialski.eu/piszczac/ img/userfiles/files/Stale/strategia_rozwoju.pdf (dostęp: 25.07.2013).

ŚLUSARZ G., 2008: Potrzeby i możliwości rozwoju współpracy transgranicznej na przykładzie Podkarpacia, [w:] Spójność społeczno-ekonomiczna a modernizacja regionów transgranicznych, M.G. Woźniak (red.), Wydawnictwo Uniwersytetu Rzeszowskiego, Rzeszów, s. 58-67.

\title{
The importance of cross-border traffic in the socio-economic development of the eastern Polish communes
}

\begin{abstract}
The aim of this research was to recognize the importance of cross-border movement for the development of communes located along the eastern border. The research was carried out in two communes: Terespol and Piszczac. The analysis showed that the communes are rural and they are characterized by a low degree of entrepreneurship. High unemployment contributes to the migration of people to urban centres or abroad. Border traffic is an important element of economic life in such regions. Entrepreneurs and traders use a passive trade policy in relation to consumers across the eastern border. Such policy raises concerns about the further cooperation. Socio-economic development of the communes requires institutional support for small businesses and improvement of professional skills of the unemployed. What is more, taking advantage of natural values to develop tourism and recreation offer and increasing trade and cooperation with companies from the East are equally significant.
\end{abstract}


